\title{
Dinamika musiman distribusi pertumbuhan ikan tapah di perairan sungai Jelai Kabupaten Sukamara
}

\author{
Seasonal dynamic of Wallago leeri growth distribution in the waters of the Jelai River, \\ Sukamara Regency \\ Muhammad Nuruddin ${ }^{1, *}$, Sulmin Gumiri ${ }^{2}$, Liswara Neneng ${ }^{2}$ \\ 1 PT Intan Kumala Sari, Distributor Semen Indonesia Group (Semen Gresik dan Semen Tonasa) Kalimantan Tengah. \\ Alamat: Jl. Rajawali KM 4.5, Toko Bangunan Harapan Jaya (Lantai 2), Palangka Raya \\ 2 Program Studi Magister Pendidikan Biologi Program Pascasarjana Universitas Palangka Raya \\ * Korespondensi: Muhammad Nuruddin (Email: nurdintoeng@gmail.com)
}

https://e-journal.upr.ac.id/index.php/jem

Received: 23 March 2021 https://doi.org/10.37304/jem.v2i2.2940

Revised: 12 April 2021
Accepted: 15 April 2021

\begin{abstract}
This study aims to determine the dynamics of the distribution of Wallago leeri growth based on the rainy season and dry season. This research method by determining the number of Wallago leeri catch from each trap, identify the growth distribution of Wallago leeri based on the season period, so that the data can describe the dynamics of the distribution of Wallago leeri growth in each area that has been determined. Based on the specified period, February which coincides with the rainy season, there are more Wallago leeri found, especially in the tributary area (Sungai Keramat), the size that dominates is $35 \mathrm{~cm}$ long and weighs 300 grams. In June which coincides with the dry season, the number of Wallago leeri is found which is decreasing compared to the rainy season period, the tributary area became the area where Wallago leeri found more than any other area, the dominant size is $40 \mathrm{~cm}$ long and weighs 700 grams. The dynamics of the distribution of tapah fish growth from February to June 2020, shows that the size of tapah fish found in tributary areas is almost the same. The results of this study indicate that the tributary area becomes the habitat for tapah fish during spawning or regeneration.
\end{abstract}

\section{Keywords}

Seasonal dynamics, distribution, Wallago leeri, Jelai river, Sukamara

\section{Intisari}

Penelitian ini bertujuan mengetahui dinamika distribusi pertumbuhan ikan tapah (Wallago leeri) berdasarkan periode musim hujan dan musim kemarau. Metode penelitian ini dengan menentukan jumlah tangkapan ikan tapah dari setiap perangkap, mengidentifikasi distribusi pertumbuhan ikan tapah berdasarkan periode musim, sehingga dari data tersebut dapat mendeskripsikan dinamika distribusi pertumbuhan ikan tapah dalam setiap kawasan yang telah ditentukan. Berdasarkan periode yang ditentukan, bulan Februari yang bertepatan dengan musim hujan ditemukan ikan tapah dengan jumlah yang lebih banyak, terutama di kawasan anak sungai (Sungai Keramat), ukuran yang mendominasi adalah panjang $35 \mathrm{~cm}$ dan bobot $300 \mathrm{gram}$. Bulan Juni bertepatan dengan musim kemarau ditemukan ikan tapah dengan jumlah yang menurun dibandingkan periode musim hujan, kawasan anak sungai menjadi kawasan yang ditemukan ikan tapah lebih banyak dari kawasan lain, ukuran yang mendominasi adalah panjang $40 \mathrm{~cm}$ dan bobot 700 gram. Dinamika distribusi pertumbuhan ikan tapah mulai bulan Februari hingga Juni 2020, menunjukan ukuran ikan tapah yang ditemukan di kawasan anak sungai hampir sama. Hasil penelitian ini mengindikasikan bahwa kawasan anak sungai menjadi habitat ikan tapah selama masa pemijahan atau beregenerasi.

\section{Kata kunci}

Dinamika musiman, distribusi, Wallago leeri, sungai Jelai, Sukamara 


\section{PENDAHULUAN}

Jumlah jenis yang melimpah cenderung lebih rentan menghadapi ancaman kepunahan, selain faktor alami ialah akibat pemanfaatan (penangkapan) yang tidak terkontrol, dan berbagai ancaman yang berkaitan dengan aktifitas manusia (faktor antropogenik) (DKJI-KKP, 2015). Jenis ikan tapah misalnya, memiliki tingkat kelimpahan yang tinggi pada beberapa habitat perairan. Berdasarkan distribusinya ikan tapah tersebar di wilayah perairan semenanjung Malaysia, Thailand, di sungai-sungai Kalimantan dan Sumatera ( $\mathrm{Ng}, 1992)$. Ikan tapah termasuk jenis ikan bernilai ekonomis, dari yang berukuran kecil, sedang hingga sangat besar, para nelayan terutama di kawasan perairan di Indonesia banyak melakukan penangkapan selama tingkat kelimpahan ikan tapah tersebut tinggi dan tanpa memperhatikan kondisi ikan tapah tersebut (anakan, atau sedang bertelur) di habitatnya (Pangestu dan Siswanto, 2020).

Berdasarkan hasil survei dari para nelayan di kawasan sungai Jelai kabupaten Sukamara, bahwa hasil penangkapan ikan tapah pada musim tertentu akan berkurang, mereka menduga karena eksploitasi berlebih ketika musim dimana keberadaan ikan tapah sedang melimpah, yaitu pada awal memasuki musim penghujan. Apabila nelayan melakukan penangkapan ikan tapah ketika sedang bermigrasi akan membuat terancamnya kepunahan ikan tapah itu sendiri, karena tidak memberikan waktu untuk ikan tapah tersebut melangsungkan pertumbuhannya. Dilihat dari masa reproduksi pada ikan tapah ini, bulan Oktober hingga Desember (awal musim hujan), ikan tapah akan melakukan migrasi ke bagian hulu sungai untuk melakukan pemijahan (Muslim, 2006). Selama pertunjukan pemijahan ikan tapah biasanya berenang secara berpasangan, muncul di permukaan perairan sambil melindungi telur-telurnya (Sokheng et al., 1999). Sebagian besar jenis ikan mempunyai waktu memijah sendiri-sendiri, seperti di daerah tropis ada yang memijah pada bulan purnama, dan ada pula memijah ketika terjadi air pasang ataupun surut. Faktor pemijahan lain adalah musim, pada daerah subtropis pemijahan biasanya terjadi oleh adanya faktor musim semi dan awal musim panas, ketika itu sumber makanan berlimpah dan tersedia waktu yang cukup bagi larva ikan untuk tumbuh lebih kuat sebelum datang musim dingin (Herjayanto et al., 2016).

Ikan tapah merupakan jenis ikan yang tahan hidup terhadap kondisi oksigen yang rendah yang sering disebut sebagai ikan blackfish (Masjudi et al., 2016). Ikan ini tergolong dalam kelompok ikan karnivora, dan merupakan ikan nokturnal yang aktif pada malam hari (Nathasya et al., 2013). Seperti halnya karakteristik habitat di sungai Jelai, bahwa habitat ikan tapah umumnya hidup di lapisan bawah sungai-sungai dan danau, terutama pada habitat yang memiliki banyak sumber makanan serta banyak memangsa ikan-ikan yang lebih kecil (lqbal, 2011). Oleh karena itu peneliti menentukan untuk mencari jumlah ikan tapah dalam distribusi pertumbuhan ikan tapah pada musim hujan dan musim kemarau, sebagai data pelengkap yaitu mengukur panjang dan bobot tubuh ikan tapah hasil tangkapan pada kedua musim sebagai tolak ukur pertumbuhan ikan tapah yang diperoleh, sehingga diperlukan kajian untuk mengetahui dapat dinamika distribusi pertumbuhan ikan tapah yang terjadi. Dengan demikian informasi ini dapat memberikan manfaat dalam pelestarian dan pengontrolan eksploitasi ikan tapah yang berlebih.

\section{METODOLOGI}

\subsection{Alat dan Bahan}

Penelitian ini dilaksanakan dalam dua periode, yaitu sebanyak 2 kali pada bulan Februari 2020 yang merupakan musim hujan di wilayah Kabupaten Sukamara. Penelitian dilanjutkan sebanyak 2 kali pada bulan Juni 2020 yang merupakan awal masuk musim kemarau. Pengambilan sampel ikan tapah dilaksanakan dengan beberapa alat dan bahan yang disediakan peneliti bersama tiga nelayan setempat sebagaimana disajikan pada Tabel 1.

Tabel 1 Alat dan bahan

\begin{tabular}{cll}
\hline No & \multicolumn{1}{c}{ Alat } & \multicolumn{1}{c}{ Bahan } \\
\hline 1. & Kamera dan alat tulis & $\begin{array}{l}\text { lkan Tapah (Wallago } \\
\text { leeri) hasil tangkapan }\end{array}$ \\
2. & $\begin{array}{l}\text { Alat ukur (meteran, } \\
\text { timbangan) }\end{array}$ & Lembar pengamatan \\
3. & $\begin{array}{l}\text { Tempirai (perangkap } \\
\text { ikan) }\end{array}$ & Umpan (Buah kelapa) \\
4. & Kelotok & \\
\hline
\end{tabular}

\subsection{Prosedur Penelitian}

Jenis penelitian yang dilakukan adalah penelitian lapangan (field research) peneliti menggunakan jenis penelitian campuran/kombinasi (mixed methodology). Mixed Method adalah penelitian yang melibatkan penggunaan dua metode, yaitu data kuantitatif dan deskriptif dalam studi tunggal (satu penelitian). Penggunaan dua metode ini dipandang lebih memberikan pemahaman yang lebih lengkap tentang masalah penelitian dari pada penggunaan salah satu diantaranya (Sugiyono, 2013).

Berdasarkan metode kombinasi, pada tahap pertama penelitian menggunakan metode kuantitatif, kemudian dilanjutkan dengan menggunakan metode deskriptif. Penekanan metode lebih pada metode pertama yaitu metode kuantitatif dan selanjutnya dilengkapi dengan metode deskriptif. Pencampuran kedua metode tersebut bersifat connecting (menyambung) antara hasil penelitian pertama dan tahap berikutnya (Sugiyono, 2013).

Penarikan sampel dalam penelitian ini terbagi menjadi dua tahap, pertama yaitu tahap penarikan sampel area yang ditentukan berdasarkan Purposive Sampling. Wilayah 
yang ditentukan melalui observasi dan pengumpulan datadata primer tentang kawasan sungai Jelai di desa Pulau Nibung yang secara geologis memiliki karakter sungai yang variatif terdiri atas sungai induk, dan beberapa anak sungai dan danau (Gambar 1). Di pedalaman Kalimantan perairan tawar dikenal dengan rawa gambut, beberapa rawa ditumbuhi oleh rumput-rumputan, sedangkan di danau dan sungai ditumbuhi eceng gondok (Suwelo, 2005).

Tahap selanjutnya adalah penarikan sampel jenis ikan tapah tersebut dilakukan dengan studi lapangan bersama nelayan setempat. Sebanyak tiga nelayan yang mengambil sampel ikan tapah tersebut, yaitu 1 orang di kawasan sungai induk, 1 orang di kawasan danau, dan 1 orang di anak sungai bagian hulu perairan. Metode pengumpulan data menggunakan metode deskriptif dengan mensintesis berbagai data dan informasi yang dikumpulkan dari lapangan dan masyarakat serta instansi terkait (Satria, 2016). Data pertumbuhan kemudian diidentifikasi melalui pengukuran panjang dan bobot ikan tapah dengan alat ukur meteran dan timbangan (Alfarizi et al., 2019).

Pengumpulan data hasil penelitian ini melalui studi lapangan secara langsung bersama nelayan (Gambar 2). Lembar pengamatan (Tabel 2) yang berisi informasi jumlah hasil tangkapan ikan tapah dibawa oleh masing-masing nelayan, kemudian data ikan tapah tersebut dikumpulkan setelah pengambilan sampel ikan tapah telah dilaksanakan untuk dilakukan pengukuran panjang dan bobot sebagai tolak ukur pertumbuhan ikan tapah (Tabel 3).
Tabel 2 Jumlah tangkapan musim hujan/kemarau

\begin{tabular}{|c|c|c|c|}
\hline $\begin{array}{c}\text { Tangkapan } \\
\text { ke- }\end{array}$ & $\begin{array}{l}\text { Nama } \\
\text { Lokasi }\end{array}$ & $\begin{array}{c}\text { Perangkap } \\
\text { ke- }\end{array}$ & Jumlah \\
\hline \multirow[t]{10}{*}{ Pertama } & & 1 & \\
\hline & & 2 & \\
\hline & & 3 & \\
\hline & & 4 & \\
\hline & & 5 & \\
\hline & & 6 & \\
\hline & & 7 & \\
\hline & & 8 & \\
\hline & & 9 & \\
\hline & & 10 & \\
\hline \multicolumn{4}{|c|}{ Total Keseluruhan } \\
\hline \multirow[t]{10}{*}{ Kedua } & & 1 & \\
\hline & & 2 & \\
\hline & & 3 & \\
\hline & & 4 & \\
\hline & & 5 & \\
\hline & & 6 & \\
\hline & & 7 & \\
\hline & & 8 & \\
\hline & & 9 & \\
\hline & & 10 & \\
\hline
\end{tabular}

Total Keseluruhan

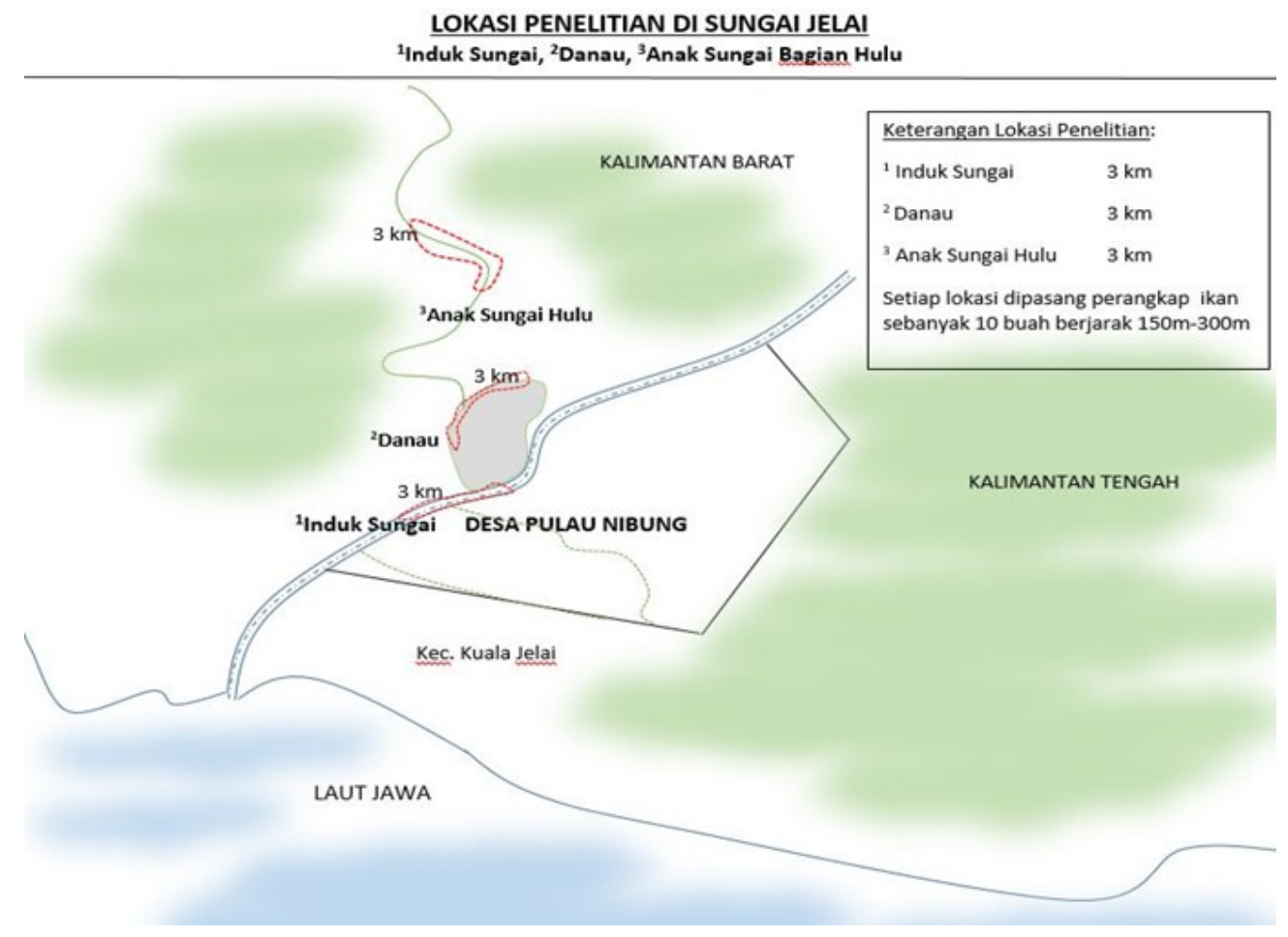

Gambar1 Lokasi penelitian 
Tabel 3 Panjang dan berat ikan tapah musim hujan/kemarau

\begin{tabular}{|c|c|c|c|c|}
\hline Tangkapan ke- & Lokasi & $\begin{array}{c}\text { Rata-rata panjang } \\
(\mathrm{cm})\end{array}$ & $\begin{array}{c}\text { Rata-rata bobot } \\
\text { (gram) }\end{array}$ & Keterangan \\
\hline \multirow{3}{*}{ Pertama } & Anak sungai & & & \\
\hline & Induk sungai & & & \\
\hline & Kawasan danau & & & \\
\hline \multirow{3}{*}{ Kedua } & Anak sungai & & & \\
\hline & Induk sungai & & & \\
\hline & Kawasan danau & & & \\
\hline
\end{tabular}
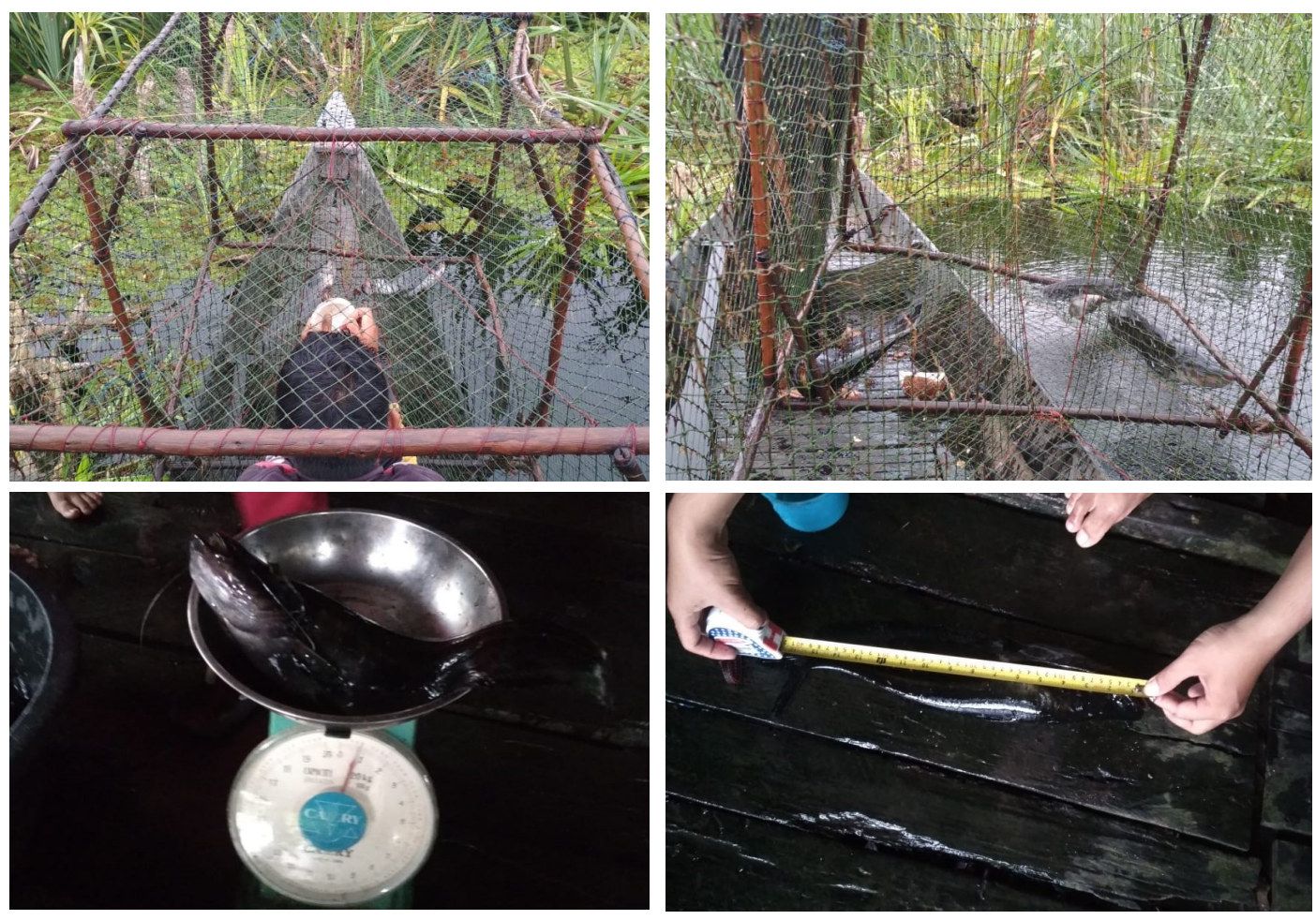

Gambar 2 Pemberian umpan hingga identifikasi ukuran sampel ikan tapah

Metode analisis data ini secara mixed method, yaitu kombinasi data hasil kuantitatif menjadi deskriptif kuantitatif. Data kuantitatif berupa data jumlah ikan tapah hasil tangkapan pada kawasan yang telah ditentukan, serta pengukuran panjang dan bobot ikan tapah yang diperoleh melalui studi lapangan bersama nelayan. Sedangkan data deskriptif kuantitatif yaitu berupa gambaran indikasi dari hasil data kuantitatif tersebut yang menentukan bagaimana dinamika musiman distribusi pertumbuhan ikan tapah itu terjadi dari perolehan hasil penelitian yang dilakukan berdasarkan periode musim dan tiga kawasan yang ditentukan. Selanjutnya data tersebut diinput melalui Microsoft excel dianalisis melalui grafik-grafik untuk mempermudah mengetahui bagaimana perbedaan jumlah tangkapan pada masing-masing kawasan, serta mengetahui bagaimana dinamika distribusi pertumbuhan ikan tapah yang terjadi baik berdasarkan periode musim maupun berdasarkan kawasan penelitian yang telah ditentukan.

\section{HASIL DAN PEMBAHASAN}

\subsection{Total Penangkapan Berdasarkan Periode}

Berdasarkan hasil penelitian pada periode musim hujan dan musim kemarau yang telah dilakukan secara langsung bersama tiga orang nelayan setempat. Perbedaan periode musim ditentukan melalui data prakiraan masuk kemarau awal bulan Juni di wilayah Kabupaten Sukamara bagian barat tahun 2020 (BMKG, 2020). Hasil penelitian ini secara umum dapat dilihat melalui Gambar 3.

Gambar 3 menunjukan bahwa ditemukan perbedaan 


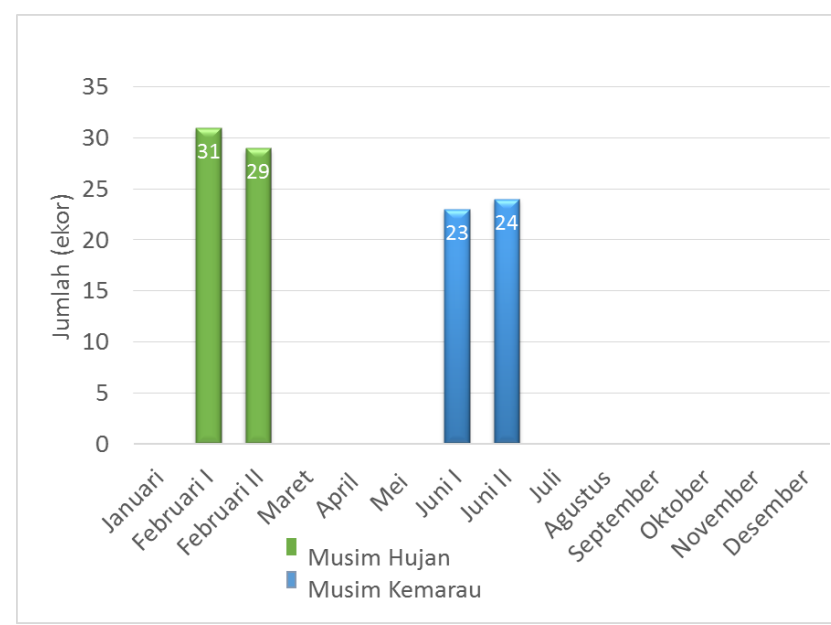

Gambar 3 Hasil tangkapan ikan tapah berdasarkan periode

jumlah hasil tangkapan ikan tapah, mulai dari bulan Februari hingga Juni jumlah ikan tapah tersebut terlihat menurun. Pada bulan Februari yang bertepatan dengan musim hujan, jumlah ikan tapah pertama sebanyak 31 ekor dan tangkapan kedua diperoleh sebanyak 29 ekor yang dilakukan secara berurutan. Sedangkan pada bulan Juni bertepatan dengan awal musim kemarau, jumlah tangkapan pertama diperoleh sebanyak 23 ekor dan tangkapan kedua diperoleh sebanyak 24 ekor. Penurunan jumlah tangkapan tersebut kemungkinan besar disebabkan oleh bermigrasinya ikan tapah, sehingga distribusi mengelompok di sungai bagian hulu saja, terutama dalam masa pemijahan pada bulan Oktober hingga Desember yang bertepatan dengan musim hujan dan perairan pasang (Muslim, 2006).

\subsection{Distribusi Pertumbuhan pada Periode Musim Hujan}

Gambar 4 dan Gambar 5 menyajikan persentase hasil penangkapan ikan tapah pertama pada musim hujan terlihat lebih banyak di kawasan anak sungai. Hasil tangkapan tersebut terdiri dari sebanyak 74\% diperoleh dari kawasan anak sungai, $19 \%$ dari kawasan induk sungai dan $7 \%$ dari kawasan danau. Sedangkan persentase hasil

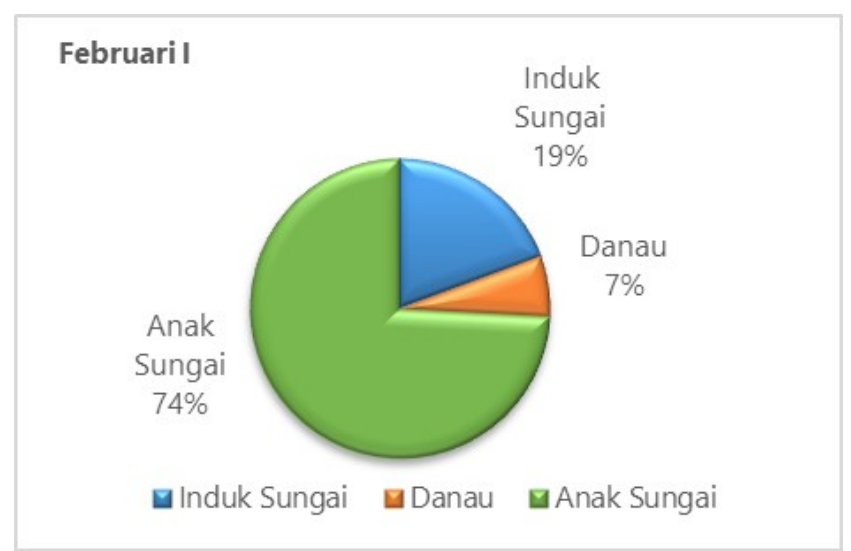

Gambar 4 Persentase tangkapan pertama Februari

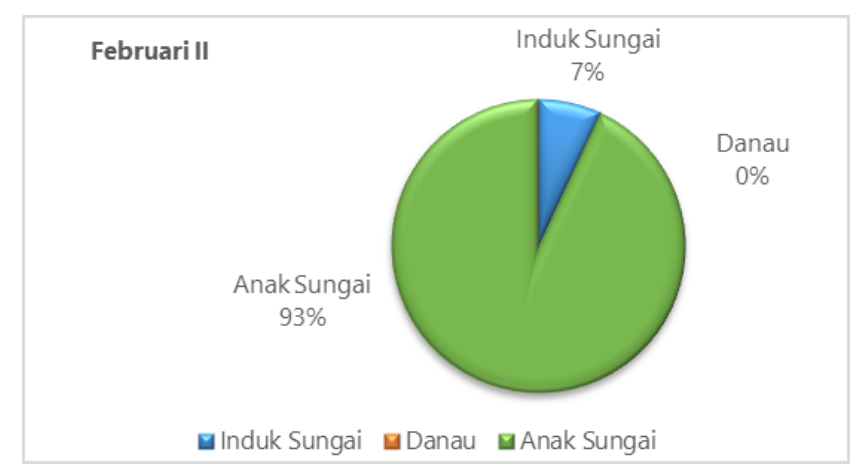

Gambar 5 Persentase tangkapan kedua Februari

penangkapan kedua cendrung lebih meningkat diperoleh dari kawasan anak sungai yaitu menjadi 93\%, sedangkan dari kawasan induk sungai cendrung menurun hanya diperoleh $7 \%$ dan di kawasan danau, ikan tapah tidak ada ditemukan (0\%). Hal ini mengindikasikan bahwa distribusi ikan tapah cendrung bermigrasi ke kawasan anak sungai.

\subsection{Distribusi Pertumbuhan pada Periode Musim Kemarau}

Ikan tapah pada hasil tangkapan pertama musim kemarau ini menunjukan penurunan jumlah perolehan dari semua kawasan. Di kawasan anak sungai diperoleh sebanyak $61 \%$, di kawasan induk sungai 30\% dan kawasan danau hanya $9 \%$ yang dianggap sebagai kawasan perantara saja (Gambar 6). Penurunan jumlah terjadi pada kawasan anak sungai tidak sebanyak perolehan saat periode musim hujan. Pengambilan sampel ikan tapah

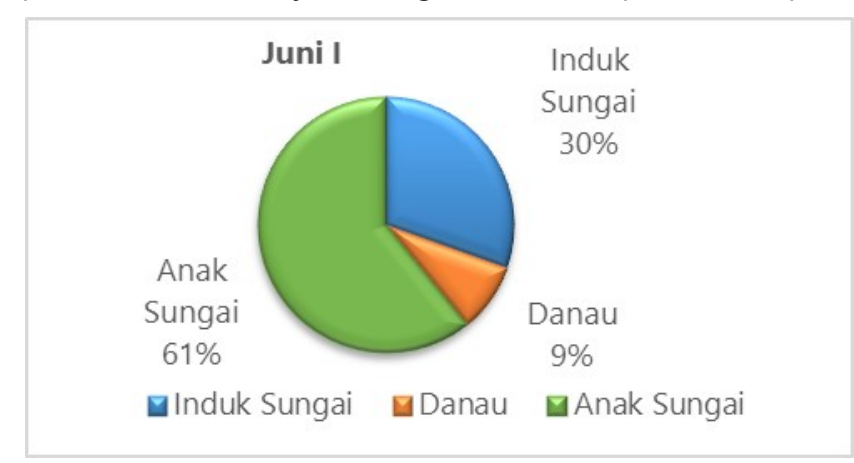

Gambar 6 Persentase tangkapan pertama Juni 2020

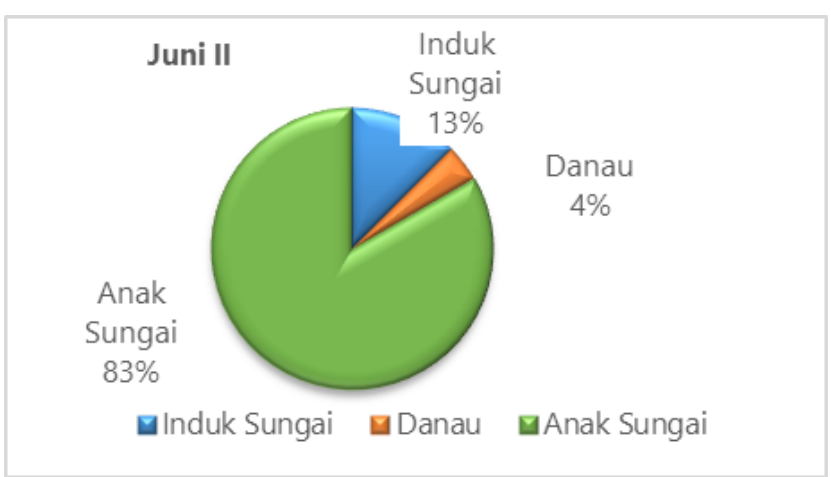

Gambar 7 Persentase tangkapan kedua Juni 2020 
kedua menunjukan bahwa hasil tangkapan kembali meningkat, terutama di kawasan anak sungai dibandingkan dari tangkapan pertama. Berdasarkan hasil tangkapan tersebut, di kawasan anak sungai diperolah 83\%, sedangkan di kawasan induk sungai yaitu $13 \%$ dan kawasan danau 4\% (Gambar 7). Hal ini mengindikasikan tidak adanya perubahan dalam distribusi ikan tapah, bahwa di kawasan anak sungai merupakan habitat yang dihuni ikan tapah untuk mencari makan maupun beradaptasi dalam masa pemijahan.

\subsection{Dinamika Distribusi Pertumbuhan Berdasarkan Periode}

Berdasarkan hasil perolehan jumlah ikan tapah pada masing-masing kawasan, terlihat adanya dinamika yang terjadi sejak bulan Februari hingga Juni 2020. Meskipun dalam hal kuantitas ikan tapah di kawasan anak sungai bersifat konstan, hal ini disebabkan karena ikan tapah melakukan migrasi yang diakibatkan oleh faktor cuaca, musim pasang surut, masa pemijahan maupun kelimpahan sumber makanan (Hussain et al., 2016). Namun selama periode musim hujan dan kemarau, ikan tapah ditemukan memiliki ukuran yang berbeda-beda, sehingga pertumbuhan ikan tapah dapat diukur melalui dinamika ini, berdasarkan pengambilan sampel ikan tapah pada setiap kawasan yang telah ditentukan, apakah kawasan tersebut tergolong habitat yang produktif atau tidak bagi ikan tapah dalam beregenerasi.

Gambar 8 menunjukan bahwa rata-rata hasil tangkapan selama musim hujan hingga musim kemarau memilik ukuran panjang dan bobot ikan tapah berbeda-beda. Di kawasan induk sungai rata-rata panjang ikan tapah musim hujan berkisar mulai $38,5 \mathrm{~cm}$ hingga $40 \mathrm{~cm}$, bobot berkisar 650 gram hingga 800 gram, musim kemarau rata-rata panjang berkisar $42 \mathrm{~cm}$ hingga $45 \mathrm{~cm}$, bobot 750 gram hingga 900 gram. Di kawasan danau pada musim hujan ukuran panjang berkisar $38,5 \mathrm{~cm}$, bobot berkisar 700 gram, musim kemarau rata-rata berukuran panjang $41 \mathrm{~cm}$ hingga $42 \mathrm{~cm}$, bobot berkisar 700 gram hingga $800 \mathrm{gram}$. Hal ini mengindikasikan bahwa ikan tapah yang ditemukan di kawasan induk sungai dan danau, merupakan ikan tapah generasi yang sama antara musim hujan dan musim kemarau.

Sedangkan di kawasan anak sungai ditemukan ikan tapah pada musim hujan dengan rata-rata ukuran panjang $39 \mathrm{~cm}$ hingga $41 \mathrm{~cm}$, bobot berkisar 650 gram hingga 700 gram. Musim kemarau ditemukan ikan tapah dengan ratarata ukuran panjang berkisar $41 \mathrm{~cm}$ hingga $39,5 \mathrm{~cm}$, bobot berkisar 700 gram hingga 670 gram. Hal ini mengindikasikan bahwa ikan tapah yang ditemukan di kawasan anak sungai merupakan generasi berbeda antara musim hujan dan musim kemarau, karena ukuran ikan
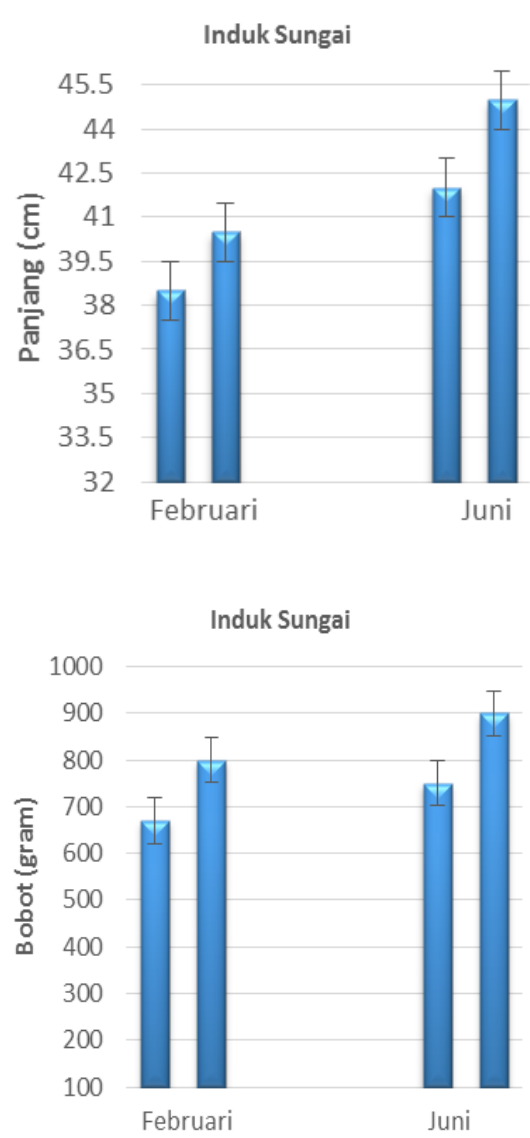
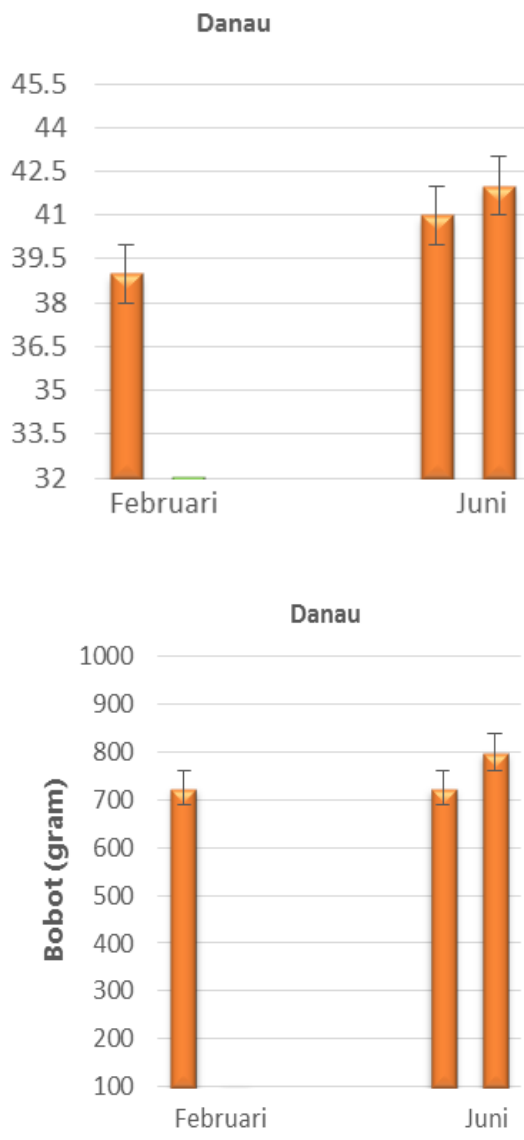
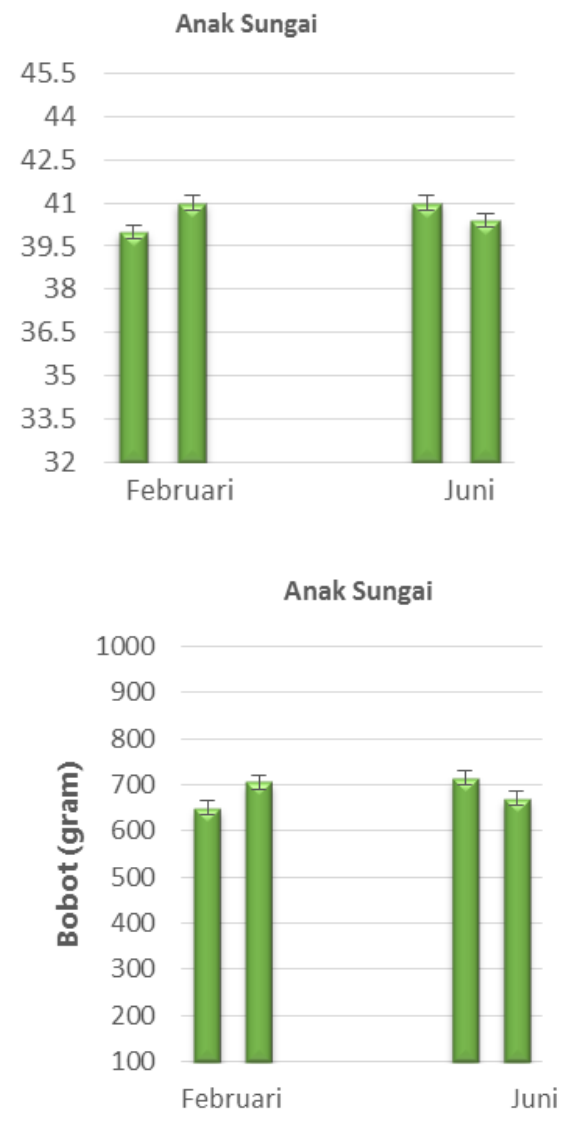
tapah yang ditemukan cendrung memiliki ukuran sama bahkan menurun selama periode bulan Februari hingga Juni, sehingga hasil tangkapan di kawasan anak sungai dapat dikatakan menjadi populasi ikan tapah dengan distribusi pertumbuhan yang produktif.

Dinamika sebaran populasi ikan tapah terjadi karena adanya perubahan iklim, berhubungan pula dengan adaptasi masa pemijahan ikan tapah dalam melakukan migrasi (Thella, 2018).

\section{KESIMPULAN}

Hasil penelitian ini menunjukan bahwa periode bulan Februari yang bertepatan dengan musim hujan, ikan tapah (Walloago leeri) ditemukan dengan jumlah lebih banyak. Sedangkan pada periode bulan Juni yang bertepatan dengan musim kemarau jumlah ikan tapah (Walloago leeri) yang ditemukan cendrung menurun. Pertumbuhan ikan tapah (Walloago leeri) yang ditemukan sangat variatif, terlihat dari ukuran ikan tapah yang diperoleh berkisar mulai panjang $30 \mathrm{~cm}$ dan bobot 200 gram hingga panjang $58 \mathrm{~cm}$ dan bobot 1500 gram. Selama periode Februari hingga Juni, di kawasan anak sungai ikan tapah (Wallago leeri) ditemukan berukuran hampir sama, sehingga mengiindikasikan bahwa ikan tapah (Walloago leeri) aktif beregenerasi di kawasan tersebut.

\section{UCAPAN TERIMA KASIH}

Penulis mengucapkan terima kasih yang sebesar-besarnya kepada Bapak Mukeram, Kaspul, dan Didi selaku nelayan yang telah membantu selama proses pengambilan sampel ikan tapah di Perairan Sungai Jelai kawasan desa Pulau Nibung Kabupaten Sukamara.

\section{DAFTAR PUSTAKA}

Alfarizi, L.R., Asrial, E. and WSK, L.A.T.T., 2019. The characteristics of morphology and gonad maturity stage of pepudah fish (Rasbora lateristriata) in Penyonggak river Lombok Timur regency. Environment and Natural Resources, 1(1), 41-50.

Anonim, 2015. Pedoman Umum Restoking Jenis Ikan Terancam Punah. Direktorat Konservasi Kawasan dan Jenis Ikan, dan Kementerian Kelautan dan Perikanan (DKKJI-KKP). Jakarta.

Anonim, 2020. Prakiraan Awal Musim Kemarau 2020 di Indonesia. Badan Meteorologi Klimatologi dan Geofisika. Jakarta.
Herjayanto, M., Carman, O., \& Soelistyowati, D. T. (2016). Tingkah laku memijah, potensi reproduksi ikan betina, dan optimasi teknik pemijahan ikan pelangi Iriatherina werneri Meinken, 1974. Jurnal Iktiologi Indonesia, 16(2), 171-183.

Hussain, M.Z., Latif, A., Shahzadah, W.A., Hussain, S., Iqbal, R. and Ali, M., 2016. Diversity, abundance and seasonal variations of fish community in lentic water bodies of Indus River at Ghazi Ghat, Pakistan. Pakistan Journal of Zoology, 48(1), 59-65.

Iqbal, M. 2011. Ikan-ikan di Hutan Rawa Gambut Merang Kepayang dan Sekitarnya. Merang REDD Pilot Project (MRPP). Palembang, Sumatera Selatan.

Masjudi, H., Tang, U.M. and Syawal, H., 2016. Kajian tingkat stres ikan Tapah (Wallago leeri) yang dipelihara dengan pemberian pakan dan suhu yang berbeda. Berkala Perikanan Terubuk, 44(3), 69-83.

Muslim, M., 2006. Aktivitas penangkapan ikan tapah (Wallago sp) di sungai Batanghari Leko Musi Banyuasin. Agria, 1(2), 117-119.

Nathasya, N., Elvyra, R. and Yusfiati, Y., 2013. Morfometrik Ikan Tapah (Wallago leeri Bleeker, 1851) Dari Sungai Siak dan Sungai Kandis Provinsi Riau (Doctoral dissertation, Riau University).

Ng, P.K.L., 1992. The giant Malayan catfish, Wallago leerii Bleeker, 1851, and the identities of Wallagonia tweediei Hora \& Misra, 1941, and Wallago maculatus Inger \& Chin, 1959 (Teleostei: Siluridae). Raffles Bull. Zool, 40, 245-263.

Pangestu, M. and Siswanto, S., 2020. Inventarisasi spesies ikan bernilai ekonomis di perairan umum Kabupaten Seruyan. Jurnal Ilmu Hewani Tropika (Journal of Tropical Animal Science), 9(1), 8-12.

Satria, H. 2016. Kajian Karakteristik Habitat dan Kelimpahan Stok Ikan Arwana Irian (scleropages jardinii) di Sungai Maro, Kumbe dan Kimaam Kabupaten Merauke, Papua. Jurnal Prosiding Forum Nasional Pemulihan dan Konservasi Sumberdaya Ikan-V.

Sokheng, C., Chhea, C.K., Viravong, S., Bouakhamvongsa, K., Suntornratana, U., Yoorong, N., Tung, N.T., Bao, T.Q., Poulsen, A.F. and Jorgensen, J.V., 1999. Fish migrations and spawning habits in the Mekong mainstream: a survey using local knowledge (basin-wide). Assessment of Mekong fisheries: Fish Migrations and spawning and the Impact of water Management Project (AMFC). AMFP Report, 2, p.99.

Sugiyono. 2013. Metode Penelitian Kombinasi (Mixed Methods). CV. Alfabeta, Bandung.

Suwelo, I.S., 2005. Spesies ikan langka dan terancam punah perlu dilindungi undang-undang. Jurnal Ilmu-Ilmu Perairan dan Perikanan Indonesia, 12(2), 161-168.

Thella, R., Dahanukar, N., Eldho, P.S., Ali, A., and Raghavan, R., 2018. Population dynamics of Wallago attu (Bloch and Schneider 1801)(Osteichthyes, Siluridae) in three small rivers of Southern India. Asian Fisheries Science, 31, 172-178. 